\title{
MEMLÛK-MOĞOL MÜCADELESİ VE ORTA DOĞU TARIHINE ETKILERI
}

\author{
YÜKSEL ARSLANTAŞ*
}

\section{Yüzyılda Türk-İslam Âleminin Genel Durumu}

XIII. asır, Orta Doğu'nun siyasi haritasında yeni şekillenmelerin ve güç dengelerinin ortaya çıktığı, Türk-İslam âleminin karışık bir asrıdır. Bu yüzyıla girerken Eyyûbi Devleti'nin en güçlü sultanı Selahaddin-i Eyyûbi'nin (1174-1193) ölümüyle halefleri arasında taht mücadeleleri başlamış, bu mücadelelerden galip çıkan bazı Eyyûbi emir ve beyleri otoritelerini tesis ettikten sonra zaman zaman Kuzey Suriye'de Türkiye Selçuklu Devleti ile hakimiyet mücadelesine girişmişlerdir. Bu durum 1250 yılında Eyyûbi hükümdarı Melik Salih Necmeddin'in (1240-1250) ölümüne kadar devam etmiş, onun ölümünden sonra başlayan karışıklıklar son Eyyûbi hükümdarı El-Melikü'lMuazzam Turanşah'in Memlûkler tarafindan öldürülmesi ve Memlûk Devleti'nin kurulmasıyla son bulmuştur (1250) ${ }^{1}$.

Bu sıralarda Bağdad Abbasi Halifeliği'nin eski gücünü kaybettiği, çeşitli İslam hükümdarlarının saltanatlarını tebrik ve tasdik etmenin yanında ortaya çıkan anlaşmazlıklarda sulh için elçi ve rica heyetleri göndermekten başka bir fonksiyonunun kalmadığı ${ }^{2}$ anlaşılmaktadır.

Bu dönemde Orta Doğu'nun siyasi haritasında söz sahibi bir devlet olan Bizans'ta da durum pek farklı değildi. İslam alemine karşı tertip edilen Haçlı Seferleri'nin dördüncüsünde Latinler, Bizans' ${ }^{3}{ }^{3}$ başkenti İstanbul'u işgal ile büyük yağma ve tahribat yapmışlar; 1260 'lara kadar devam eden bu işgal ve karışıklık, Bizans'ta daha önce var olan otorite boşluğu ve güç kaybının artmasına sebep olmuştu ${ }^{4}$.

•Dr.Araşurma Gōrevlisi, Fırat Üniversitesi, Fen-Edebiyat Fakültesi Tarih Bölümü, ELAZIĞ.

${ }^{1}$ Kâzım Yaşar Kopraman, "Memlûkler", Doğuștan Günümüze Büyük İslam Tarihi, C. 6, İstanbul 1987, s. 433-456; Süleyman Özbek, "Moğol İstilasının Durak Noktası Ayn-ı Câlût Savaşı ve Sonuçlarn", Askeri Tarih Bülteni, S. 31, (Ağustos, 1991), Ankara, 1991, s. 11.

2 Süleyman Özbek, "Moğol İstilasının Durak Noktası Ayn-ı Câlût Savaşı ve Sonuçları", s. 11.

${ }^{3}$ Bizans Devleti hakkında bkz. G. Ostrogorsky, Bizans Devleti Tarihi (Çev. Fikret Işıltan), Ankara, 1981.

${ }^{4}$ Süleyman Özbek, "Moğol İstilasının Durak Noktası Ayn-1 Câlût Savaşı ve Sonuçları", s. 1112. 
Türkiye Selçukluları Devleti'ne gelince: 1219 yılında Selçuklu tahtına oturan Alaeddin Keykûbad (1219-1237) takip ettiği siyasetle, kısa zamanda devletine en parlak devrini yaşatt. Batıya doğru süratle ilerleyen Moğol istilasının ülkesini de tehdit etmekte olduğunu fark ederek çeşitli tedbirlere baş vurdu. Öncelikle Konya, Sivas ve Kayseri gibi pek çok şehrin surlarını tamir ve tahkim ettirerek Moğollar'a karşı Harezmşahlar ve Eyyûbiler ile ittifak kurma yoluna gitti ${ }^{5}$. Ne var ki Azerbaycan'ı yurt edinen Celaleddin Harezmşah'ın böyle kritik bir zamanda Alaeddin Keykûbâd'la işbirliği yapmak yerine Selçuklu topraklarına tecavüzde bulunması bu iki Türk devletinin $1230 \mathrm{yı-}$ lında Yassıçemen'de savaşa tutuşmasına sebep oldu. Savaşı kaybeden Celâleddin Harezmşah için bu mağlubiyet bir son oldu.

Alaeddin Keykûbâd'in bir süre sonra Eyyûbiler ile Kuzey Suriye toprakları konusunda mücadeleye başlaması onun ikinci müttefikini de kaybederek Moğollar karşısında yalnız kalmasına sebep oldu. 1236 yılında Alaeddin Keykûbad, Eyyûbiler üzerine sefer yapmaya hazırlanırken Moğol Hanı Ögedey'in (1229-1241) elçilere gelerek yıllık vergi vermesini ve Moğol hanına tabiiyetini arz etmesini bildirdiler. Moğollar'a karşı tek başına mücadele edemeyeceğini anlayan Alaeddin Keykûbâd bu istekleri kabul etti. Böylece Moğol tehlikesini bir süre için de olsa ülkesinden uzaklaşturmış oluyordu ${ }^{6}$.

Alaeddin Keykûbad'dan sonra tahta geçen II.Gıyaseddin Keyhüsrev (1237-1246) zamanı Türkiye Selçuklu Devleti için adeta bir yıkım devresi oldu. O'nun kötü idaresi yanında Moğollar da Baycu kumandasında büyük bir ordu ile Anadolu'ya girerek fiilen istila teşebbüsünde bulundular. 1243 yılında Kösedağ ve 1256 'da Sultan Hanı civarında yapılan iki savaşta Selçuklu ordusu bozguna uğradı. Bunu müteakip Anadolu'yu istila eden Moğollar başta Sivas, Kayseri ve Erzincan olmak üzere pek çok şehri yağma ve tahrip ettiler. Bu durum karşısında Anadolu'da büyük bir karışıklık baş gösterdi. Halk panik halinde ya Bizans sınırına yakın uçlara, Bizans'a veya Suriye'ye iltica etti.

1251 yllında Moğol idaresini ele alan Mönge (1251-1259) Cengiz Han tarafından başlatulıp Ögedey zamanında da kısmen takip edilen fetih hareketlerini devam ettirmek istiyordu. Bu maksatla kardeşi Hülagu'yu büyük bir

\footnotetext{
${ }^{5}$ Osman Turan, Selçuklular Zamanında Türkiye, İstanbul 1991, s. 331-332; Süleyman Özbek, "Moğol İstilasının Durak Noktası Ayn-ı Câlût Savașı ve Sonuçları", s. 12.

${ }^{6}$ Osman Turan, a.g.e., s. 379-386; Süleyman Özbek, "Moğol İstilasının Durak Noktası Ayn-ı Câlût Savaşı ve Sonuçları", s. 12.
} 
kuvvetle İran ve Azerbaycan' in fethi ile görevlendirdi ${ }^{7}$. Hülagu emri altundaki bu ordu ile kısa zamanda Bâtunilerin merkezi Alamut'u yerle bir ederek İran'in fethini tamamladı ${ }^{8}$. Daha sonra Irak'a yönelen Hülagu, 1258'de Bağdad'ı ele geçirerek buradaki Abbasi Halifeliği'ne son verdi. Böylece Suriye sınırına dayanmış oldu. Olayların bundan sonra ki kısmı çalışmamızın konusu olan Memlûk-Moğol mücadelesini oluşturmaktadır.

\section{Kutuz'un Moğollar'la Mücadelesi ve Ayn-ı Câlût Savaşı}

Eyyûbilerin yıkılmasından sonra Memlûkler Mısır ve Suriye'ye hakim oldu ve bu devlet Moğollar için aşıllmaz bir engel teşkil etti. XIII. yüzyılda başlayan Memlûk-Moğol mücadelesi sırasında Kuzey Suriye, Moğollar ve Memlûkler arasında el değiştirdiği gibi bu bölgede bulunan bir çok siyasi teşekkül ya varlığını kaybetmiş ya da Moğollar'a tabi olarak varlıklarını sürdürmüşlerdir.

Azerbaycan'ı kendisine merkez edinerek Moğollar'ın Ön Asya temsilciliğini yapan Hülagu Suriye ve Mısır'ı itaat altına alma faaliyetlerine girişti. Bu sırada Suriye'nin siyasi yönden parçalanmış olması şartları onun için elverişli hale getiriyordu ${ }^{9}$.

Memlûk Sultanı Aybek'in 1259 yılında katlinden sonra Memlûk tahtına oturan El-Melik El-Muzaffer Kutuz (1259-1260) yaklaşmakta olan Moğol tehlikesinin farkındaydı. Zaten Hülagu da Suriye'ye doğru hareket etmeden önce bölgeye müteaddit mektuplar gönderip tehditler savurarak burada bulunan bey ve kumandanlarm kendisine itaat etmelerini istedi. Ancak bunlardan netice alamayınca sefer hazırlıklarına başladı ${ }^{10}$. Kutuz, Moğollara karşı koyabilmek için Suriye ve Mısır'da ortak bir güç teşkil edilmesi gerektiğini,

${ }^{7}$ Bertold Spuler, Iran Moğolları, (Çev. Cemal Köprülü), Ankara, 1987, s.59; Süleyman Özbek, "Moğol İstilasımın Durak Noktası Ayn-ı Câlût Savaşı ve Sonuçları", s. 12-13.

${ }^{8}$ Süleyman Özbek, "Moğol İstilasının Durak Noktası Ayn-ı Câlût Savaşı ve Sonuçları", s. $12-13$.

${ }^{9}$ Makrizi, Kitâbu's-Sülük li-Ma'rifet-i Düveli'l-Mülûk (Yay. M. Ziyade), C. 1, 2, Kahire, 1987, s. 418-419; Ibn Haldun, Kitabu'l-Iber ve Divanu'l-Mübteda ve'l-Haber, C.5, Beyrut, 1987, s. 437 vd; Bertold Spuler, a.g.e., s. 59-77; Abdulkadir Yuvalı, Ilhanlılar Tarihi, Kayseri, 1994, s. 52 , 82; Süleyman Özbek, "Moğol İstilasının Durak Noktası Ayn-ı Câlût Savaşı ve Sonuçları", s.14; Steven Runciman, Haçlı Seferleri Tarihi, C.3, İstanbul, 1992, s.254-262.

10 "Makrizi, Kitab-1 Sülûk li Ma'rifet-i Düveli'l Mülùk, C.1, K.2, s.419; İbn Haldun, Kitabu'lİber ve Divanu'l-mübteda ve'l-Haber, C.5, s.437 vd; Bertold Spuler, a.g.e., s. 59-77; Steven Runciman, Haçlı Seferleri Tarihi, C.3, s.259-260; Süleyman Özbek, "Moğol İstilasının Durak Noktası Ayn-ı Câlût Savaşı ve Sonuçları", s.14; Abdulkadir Yuvalı, Ilhanlılar Tarihi, s. 83-84. 
mahalli kuvvetlerle bunlara karşı koymanın mümkün olamayacağını düşünüyordu. Bu sebeple bütün dikkat ve gayretini Moğollara karşı koyabilecek güçlü bir ordu teşkiline yoğunlaşturdı. Böylece Moğollara karşı bir cihat hareketi başlatt.

Memlûk sultanının açmış olduğu cihat bayrağı altına kısa sürede Suriye ve Mısır'dan katılmalar başladı. Bunlar arasında en önemlisi Aybek zamanında Mısır'dan firar eden Bahrî Memlûkler'in katılımıydı. Suriye'de bulunan Bahrî Memlûkler, Baybars el-Bundukdarî idaresinde Mısır'a dönmek ve Moğollar'a karşı mücadele etmek için Kutuz'dan izin istediler. Moğol tehlikesi karşısında eski düşmanlıkların bir süre için de olsa unutulması gerektiğini düşünen Kutuz, bu teklifi memnunlukla karşıladı. Bahri Memlûkleri Kahire dışında karşılayan Kutuz onların lideri Baybars'a Kalyob şehrini ikta olarak verdiği gibi Moğollarla yapılacak harpten sonra da Halep naipliğini vaadetti ${ }^{11}$.

Bu arada Kuzey Suriye'de ilerleyen Moğollar, Ermeni ve Haçlı kuvetlerinin yardımı ile Haleb ve Dımaşk'ı ele geçirdiler. Böylece kendisine Mısır yolu açılan Hülagu, sefer için son hazırlıklarını yaparken Büyük Moğol Hanı Mönge'nin ölüm haberini aldı. Bu haber üzerine Suriye'ye Kitboğa idaresinde 12 bin kişilik bir Moğol kuvveti bıraktı ve yeni Moğol hanının seçiminde bulunmak üzere ordusunun büyük bir kısmı ile birlikte Karakurum'a döndü. Dönüşünden önce Memlûk Devleti'nin tabiiyetini sağlamak istediğinden giderayak Kutuz'a bir elçi göndererek ondan kendisine tabi olmasını, aksi halde Haleb ve Dımaşk'ın ele geçirilmesi sırasında yaşananların ayniyle Mısır'da da vâki olacağını bildirdi' ${ }^{12}$.

${ }^{11}$ Makrizi, Kitābu's-Sülūk li-Ma'rifet-i Düveli'l-Mülük, C.1, 2, s.422; İbn Haldun, Kitabu'lIber ve Divanu'l-Mübteda ve'l-Haber, C.5, s.436; Bertold Spuler, a.g.e., s. 80; Sahabettin Tekindağ, Berkuk Devrinde Memlûk Sultanlı̆ı, İstanbul 1961, s.29; Steven Runciman, a.g.e., C.3, s.260; Kâzım Yaşar Kopraman, "Memlūkler", Doğuştan Günümüze Büyük İslam Tarihi, s.452-453; J.B. Globb, Soldiers of Fortune, London, 1973, s.57-64; Süleyman Özbek, "Moğol İstilasımın Durak Noktası Ayn-ı Câlût Savaşı ve Sonuçları", s.15; Abdulkadir Yuvalı, İhanlılar Tarihi, s.89-91.

${ }^{12}$ Makrizi, Kitābu's-Sülūk li-Ma 'rifet-i Düveli 1-Mülūk, C.1, K.2, s.420; İbn Haldun, Kitabu'lIber ve Divanu'7-mübteda ve'l-Haber, C.5, s.436; Bertold Spuler, a.g.e., s.59-88; Steven Runciman, a.g.e., C.3, s.260; Kazım Yaşar Kopraman, "Memlûkler" Doğuştan Günümüze Büyük İslam Tarihi, s.452-453; Süleyman Özbek, "Moğol İstilasının Durak Noktası Ayn-ı Câlût Savașı ve Sonuçları", s. 15; Abdulkadir Yuvalı, İlhanlılar Tarihi, s. 89-91. 
Hülagu'nun bu tehdit dolu talebi karşısında Memlûk ümerasını toplayan Kutuz, onlarla durumu istişare etti. İstişarede savaş kararı alınınca Moğol elçilerinin vücutları ortadan ikiye bölündü ve başları da Kahire sokaklarında dolaşurıldı. Hülagu'nun tehdit dolu teslim teklifine aynı şekilde cevap verilince iki devlet arasında savaş kaçınılmaz hale geldi ${ }^{13}$.

Kutuz bu sırada siyasi bir manevra ile Akkâ'da bulunan Haçlılar ile anlaşarak onların tarafsızlı̆̆ını sağladı ${ }^{14}$.

Karşılıklı ilişkilerin bu derece gerginleşmesi üzerine son hazırlıklarını tamamlayan Memlûk Sultanı, ordusu için gerekli mali desteği Mısır halkına koyduğu ağır vergilerle karşıladı. Daha sonra Memlûk ümerası ile yaptığı son bir istişareden sonra Emir Baybars el-Bundukdarî'yi öncü birliklerin kumandanlığına ayin ederek Moğollar hakkında bilgi toplaması için gönderdi. Bir süre sonra da asıl Memlûk ordusu Sultan'ın liderliğinde Kahire'den ayrıldı.

1260 yllında Kahire'den hareket eden Memlûk ordusu Sâlihiyye'ye geldi. Burada Sultan Kutuz, etrafa adamlar göndererek cihat çağrısı yaptı ve cihada katılmayanlara gerekirse zor kullanılmasım istedi.

Memlûk ordusu Sâlihiyye'de iken bazı Memlûk emirleri arasında tereddüt ve korku emareleri ortaya çıkmaya başladı. Emirler, Moğollar ile yapılacak bu savaşta hezimete uğramaları halinde Bağdad'ın başına gelenlerin Kahire'nin de başına gelebileceğini söyleyerek karşı koymanın manasız oldugunu iddia ediyorlardı. Bu nazik durum karşısında emirleri toplayan Kutuz, onlara hitaben: "Sizler bunca zamandır beytü'l-malın ekmeğini yiyor, cihat zamanında ise savaştan kaçıyorsunuz. Ben cihada gidiyorum. İsteyen be nimle gelsin, istemeyen evine dönsün"15 mealindeki tahrik ve teşvik edici konuşmayı yaptı. Bu tesirli hitabdan sonra Memlûk ordusu yek vücut bir halde Moğollar üzerine yürüyüşe geçti.

${ }^{13}$ Makrizi, Kitābu's-Sülūk li-Ma'rifet-i Düveli'l-Mülūk, C.1, K.2, s.423; Süleyman Özbek, "Moğol İstilasının Durak Noktası Ayn-ı Câlût Savaşı ve Sonuçları", s.15.

${ }^{14}$ Makrizi, Kitābu's-Sülūk li-Ma'rifet-i Düveli'l-Mülūk, C.1, K.2, s.423; Şahabettin Tekindağ. "Memlûk Sultanlı̆̆ı Tarihine Toplu Bir Bakıs", İstanbul Üniversitesi Edebiyat Fakültesi Tarih Dergisi , S. 24, İstanbul 1971, s.9; Bertold Spuler, a.g.e., s.80; Süleyman Özbek, "Moğol İstilasının Durak Noktası Ayn-ı Câlût Savaşı ve Sonuçları", s.15; Abdulkadir Yuvalı, IIhanlılar Tarihi, s.89-91.

${ }^{15}$ Makrizi, Kitābu's-Sülūk li-Ma'rifet-i Düveli'l-Mülūk, C.1, K.2, s.429; Betold Spuler, a.g.e., s.57-59; Kâzım Yaşar Kopraman, "Memlûkler", Doğuştan Günümüze Büyük İslam Tarihi, s.452453; Süleyman Özbek, "Moğol İstilasının Durak Noktası Ayn-ı Câlût Savaşı ve Sonuçları", s. 16; Abdulkadir Yuvalı, IIhanlılar Tarihi, s.89-91. 
Moğollar hakkında bilgi toplamak üzere hareketine devam eden öncü birlik, Moğol işgali altunda bulunna Gazze'ye yöneldi. Baybars kumandasındaki öncü kuvvetinin yaklaştığını haber alan Moğol kumandanı Baydara, derhal Baalbek'te bulunan Kitboğa'ya haber göndererek az sayıda asker olduğunu ve acele yardım göndermesini istedi. Kitboğa ona yardım göndermediği gibi yerinde kalmasını ve savaşmasını emretti. Fakat az sayıdaki Moğol kuvveti Baybars karşısında tutunamadı ve Memlûk öncü birliği Moğollar'ı kısa sürede bozguna uğrattı. Bu haber Mısır'da büyük bir sevinçle karşılandı.

Memlûk Sultanı Kutuz'un Moğollar'la yapacağı büyük savaştan önce dikkatli ve tedbirli bir politika takip ettiği görülmektedir. Daha önce Irak ve Suriye'de Müslümanlara karşı oluşturulan Moğol-Ermeni-Haçlı ittfakını göz önünde bulunduran Kutuz böyle kritik bir zamanda Suriye'deki Haçlı kontlukları ile çatışmaya girmekten kaçınıyordu. Onları gücendirmemek amacıyla da Akkâ'dan geçerken buradaki Haçlılardan geçiş izni istedi. Daha önce bazı Moğol birliklerinin Haçlı kontluklarına saldırıda bulunması onların Müslümanlardan sonra sıranın kendilerine geleceğini düşünmelerine sebep oluyordu $^{16}$. Bu yüzden Haçlılar, Memlûk Sultanı'na kendi topraklarından rahatlıkla geçebileceğini bildirdikleri gibi Moğollar'a karşı savaşmak için asker vermeyi dahi teklif ettiler. Daima ihtiyatlı ve tedbirli hareket etmeyi tercih eden Kutuz, savaş esnasında onların muhtemel bir ihanetine uğramamak için bu teklifi teşekkür ederek geri çevirdi ${ }^{17}$.

Ordusuyla Haçlı arazisinden rahatlıkla geçen Kutuz, Ayn-ı Câlût mevkiine geldi. Moğollara askerinin az olduğu izlenimini vermek için ordusunun büyük bir kısmını yakında bulunan ormana sakladı ve Moğollar'a karşı sadece Baybars idaresindeki öncü birlikleri ileri sürdü. 3 Eylül 1260 tarihinde sabahın ilk ışıkları ile birlikte Moğol saldırısı başladı. Bu saldırı karşısında bir süre savaşan Baybars daha sonra süratle asıl Memlûk kuvvetlerinin bulunduğu yere çekildi. Memlûk kuvvetlerinin bozgun halinde kaçtığını sanan Moğol kumandanı Kitboğa, çekilen Memlûk ordusunun takip edilmesi emrini verdi. Fakat kısa süre sonra Memlûk ordusu tarafindan kuşatılan Kitboğa, tuzağa düştüğünü anlamakta gecikmedi. Buna rağmen savaşı bırakma-

${ }^{16}$ Makrizi, Kitab-ı Sülûk li Ma'rifet-i Düveli'l Mülûk, C.1, K.2, s.429; Bertold Spuler, a.g.e., s. 57-64; Kazım Yaşar Kopraman, "Memlûkler", Doğuştan Günümüze Büyük İslam Tarihi, s.452453; süleyman Özbek, "Moğol İstilasının Durak Noktası Ayn-ı Câlût Savaşı ve Sonuçları", s.16; Abdulkadir Yuvalı, Ilhanllar Tarihi, s.89-91.

${ }^{17}$ Makrizi, Kitab-1 Sülûk li Ma'rifet-i Düveli'l Mülûk, C.1, K.2, s.429; J.B. Globb, a.g.e., s.5963; Süleyman Özbek, "Moğol İstilasının Durak Noktası Ayn-ı Câlût Savașı ve Sonuçları", s.16. 
yarak bütün gayreti ile saldırıya geçti. Moğolların çetin saldırısı kaşısında Memlûk ordusunun sol kanadı bozuldu. Bu tehlikeli durumu fark eden Memlûk Sultanı Kutuz bizzat kendisi yardımcı kuvvetlerin başında savaşa katuldı. Sultanın savaş alanında şecaatle dövüştüğünü gören Memlûk ordusu kısa zamanda toparlanarak Moğol kuvvetlerini püskürttü. Bir süre sonra bozgun emareleri gösteren Moğol ordusu kaçmaya başladı. Kaçanlar Beysan mevkiinde yeni bir müdafaa hatu kurdular. Moğolların buradaki gayretleri de onları yenilgiden kurtaramadı. Kaçanlar Baybars tarafindan Humus'a kadar takip edilerek kılıçtan geçirildi. Savaş alanında ölen Kitboğa'nın kesik haşı teşhir için Kahire'ye gönderildi ${ }^{18}$.

Moğollara karşı kazanılan bu zafer bütün İslam aleminde sevinçle karşılandı. Moğollarla işbirliği yapan bazı Eyyûbi emirleri savaştan sonra Memlûk Sultanı'nın huzuruna gelerek af dilediler. Banyas ve Subeybe emiri Melik Said Hasan dışındaki bütün Eyyûbi emirleri affedildi. Melik Said Hasan'ın ise boynu vuruldu.

\section{Ayn-ı Câlût Savaşı'nın Kazanılmasına Tesir Eden Faktörler}

Hülagu'nun yeni Moğol hanını seçmek için giderken ordusunun bir kısmını beraberinde götürmesi ve Kitboğa idaresinde az sayıda kuvvet kalması Moğol yenilgisinin ana sebeplerinden birini teşkil eder. Bu durum savaştan önce Memlûk ordusunda var olan moral bozukluğunu büyük ölçüde bertaraf etmiștir. Ayrıca Hülagu'nun bizzat ordusunun başında bulunmayışı da sonucu etkilemiştir. Memlûk Sultanı Kutuz'un ordusunun başında olması askerlerine moral verdiği gibi savaşın en kritik anında savaşa müdahalesi de Memlûkler'in mutlak bir bozgununa mani olmuştur.

Suriye'deki Haçlı kontluklarının savaş esnasında takip ettiği tarafsız siyaset de sonucu etkileyen bir başka faktördür. Daha önce Moğollara Suriye'de yaptkları istila hareketlerinde Kilikya Ermeni Krallığı ile birlikte yardımcı olan Haçlıların Ayn-ı Câlût savaşında Memlûk Sultanı Kutuz'a verdikleri söze bağlı kalarak savaşa iştirak etmemeleri Memlûk Devleti'nin işini büyük ölçüde kolaylaşurmıştur.

${ }^{18}$ Makrizi, Kitab-ı Sülûk li Ma'rifet-i Düveli'll Mülûk, C.1, K.2, s.430-431; İbn Haldun, Kitabu'l-İber ve Divanu'l-Mübteda ve'l-Haber, C.V, s.436; Steven Runciman, a.g.e., C.3, s.266; Bertold Spuler, a.g.e., s. 57-59 J.B. Globb, a.g.e., s.59-63; Süleyman Özbek, "Moğol İstilasının Durak Noktası Ayn-ı Câlût Savaşı ve Sonuçları", s.16; Abdulkadir Yuvalı, ilhanhlar Tarihi, s.8991. 
Burada unutulmaması gereken bir nokta da Bahrî Memlûkler'in göstermiş oldukları şecaat ve cesarettir. Ayn-ı Câlût'a kadar karşılarına çıkan bütün mukavemet güçlerini rahatlıkla ezip geçen Moğollar, ilk defa Ayn-ı Câlût'ta disiplinli ve eğitimli bir ordu ile karşılaştı. Nitekim karşılaştukları bu yeni gücün eğitim, disiplin, taktik ve cesaretleri karşısında şaşkınlığa düşen Moğollar daha sonraları Memlûkler'e karşı yaptıkları askeri hareketlerde de başarısız oldular.

\section{Ayn-ı Câlût Savaşı'nın Neticeleri}

Moğol ordusunun aldığı ilk meydan savaşı mağlubiyeti olan Ayn-ı Câlût Savaşı, neticeleri itibari ile İslam tarihinin en önemli savaşlarından birisidir. Bu savaş her şeyden önce Mısır Memlûkleri Devleti'nin temellerini sağlamlaşturmıştur. Suriye ve civarını da Memlûk hakimiyetine sokmuştur. Bu savaş, aynı zamanda Eyyûbiler'in kati sonudur. Artık Eyyûbi hanedanına mensup şahıslardan hiçbiri saltanat iddiasında bulunamamıştır. Nitekim onları ciddi bir rakip olarak görmeyen Kutuz, Moğollara katılan Melik Said'in dışındakileri affetmiştir.

Ayn-ı Câlût Savaşı Haçlı-Moğol işbirliğine de darbe vurmuş, Moğollar Suriye'yi boşaltmışlardır.

Memlûkler'in kazandığı bu zafer, dünya hakimiyetine koşan Moğolların yenilemeyeceği fikrini yıkmıştur. Mısır ve Suriye başta omak üzere İslam dünyası ve hatta Avrupa, Moğol istilasından kurtarılmıştır. Bu büyük zaferden sonra Memlûk Sultanları kendilerini haklı olarak İslam'ın hamisi saymaya başlamışlardır. Bu sayede bütün Müslümanların muhabbetini kazanmışlardir ${ }^{19}$.

Eğer Moğollar, Ayn-ı Câlût savaşını kazanmış olsalardı Mısır'a kadar ilerleyecekler, Irak'ta yerleştikleri gibi Mısır ve Suriye'ye de yerleşeceklerdi. Bu savaşın kazanılmasında Hülagu'nun, Karakurum'a dönmesinin ve Haçlıların tutumunun büyük rolü olmuştur. Ama her hareketin nihai bir noktaya ulaşuktan sonra duracağı da göz önüne alınmalıdır. Suriye Moğollar'ın güneybauda ulaşuğı en son nokta olmuştur. Asıl merkezlerinden uzaklaşmıs olmaları

${ }^{19}$ Makrizi, Kitābu's-Sülūk li-Ma'rifet-i Düveli'l-Mülūk, C.1,K.2, s.432; İbn Haldun, Kitabu'tIber ve Divanu'l-Mübteda ve'l-Haber, C.V, s.436; Sahabettin Tekindağ. Berkuk Devri, s.29; J.B.Globb, a.g.e., s.57-64; Kazım Yaşar Kopraman, "Memlûkler", Doğuştan Günümüze Büyük İslam Tarihi, s.452-453; Bertold Spuler, a.g.e., s.57-59; Steven Runciman, a.g.e., C.3, s.260-262; Abdulkadir Yuvalı, a.g.e., s.89-91. 
ve zaptettikleri geniş ülkelere sahip olmak için insan kaynakları kafi gelmediğinden burada durdurulmuşlardır.

Ayn-ı Câlût'taki zaferin en mühim neticelerinden birisi de XII. yüzyıldan beri Nureddin Mahmûd Zeengî ve Selahaddin Eyyûbi'nin bütün gücü ile çabalayarak temin ettikleri Suriye ve Mısır'in birliğinin, Memlûkler ile Eyyûbiler arasında parçalanmışken, tekrar temin edilmiş olmasıdır. Ancak bu birliğin sağlanmasında Eyyûbi hanedanı mensuplarının rolü olmamıştır. Bilakis onlar Moğollar ile mücadelede gereği gibi kararlı davranmamışlar ve hatta onlara teslim olarak, Ayn-ı Câlût'ta Müslümanlara karşı savaşmışlar ve bu sebeple Müslümanların gözündeki mevkilerini kaybetmişlerdir. Bunun neticesi olarak Eyyûbiler'in artık hükümdarlık yapmaya layık olmadıkları kanaati hasıl olmuştur ${ }^{20}$. Zaten ondan sonra da hakimiyetlerini büyük ölçüde kaybettiler. Ancak Suriye'deki bazı şehirlerde küçük hanedanlıklar halinde kısa bir süre daha varlıklarını sürdürebildiler.

\section{Baybars ve Moğollar}

Ayn-ı Câlût Savaşı'ndan sonra Kutuz'un Baybars'a vadettiği yerleri vermemesi sebebiyle Baybars ile Kutuz arasında başlayan mücadele Kutuz'un ölümü ile neticelendi. Kutuz'u ortadan kaldıran Baybars Memlûk tahtuna oturdu. Ancak Kutuz'un öldürülmesinden sonra ortaya çıkan karışıklıklardan faydalanıp Ayn-ı Câlût'un hıncını almayı hedefleyen Moğollar hazırlıklara başladılar. Çok geçmeden de taarruza geçtiler. Harran ve el-Cezire bölgesinde toplanan Moğol birlikleri Baydara komutasında Birecik (Bire) üzerine yürüdüler. Birecik halkının Haleb naibinden yardım istemesi neticesinde yardıma gelen birliklerin komutanı Birecik civarında düşmanla karşılaşınca askerlerinin azlığı sebebiyle savaşa cesaret edemedi ve Birecik'e gitti. Onu takip eden Moğollar, birçok askerini öldürdüler. Bu haber Haleb'e ulaşnca halk güney istikametinde kaçmaya başladı. Haleb ümerası, kötü idaresi sebebiyle, şehir naibini görevden alarak yerine Emir Hüsameddin Çevkendar'ı geçirdi. Moğolların gelişini duyan yeni naib Dımaşk'a çekilmek üzere Haleb'den ayrıldı. Bu arada Haleb'e gelen Moğollar, halkın bir çoğunu öldürdükten sonra Hama istikametinde yollarına devam ettiler.

${ }^{20}$ Makrizi, C.1, K.2, s.430-431; İbn Haldun, Kitabu'l-Iber ve Divanu'l-Mübteda ve'l-Haber, C.V, s.436; Şahabettin Tekindağ. Berkuk Devri, s.29; Bertold Spuler, a.g.e., s.57-64; Steven Runciman, a.g.e., C.3, s.264-267; Faruk Sümer, "Anadolu'da Moğollar" Selçuklu Araşurmaları Dergisi, S.1, İstanbul, 1969, s.15-27; Abdulkadir Yuvalı, "Hülagu Han'ın Bau Seferinin Türkiye Tarihi Yōnünden Değerlendirilmesi" Milli Kültür, Mart, 1984, s.44. 
Moğollar'la savaşın kaçınılmaz olduğunu gören Haleb, Hama ve Humus ümerası savaşa karar vererek Moğollar üzerine yürüdü ve onları mağlup ederek bir çoğunu öldürdü. Bu sırada Sultan Baybars'ın Moğol işgali altundaki Haleb'i kurtarmak için teçhiz ettiği ordu yola çıktı. Bu ordu Gazze'ye ulaştuğı sırada bölgedeki Haçlılar durumu Moğollar'a haber verdi. Bunun üzerine Moğollar şehri tahliye etti ve şehir Müslümanların eline geçti.

Bu tarihlerde yaklaşık 9 ay Moğol muhasarasında kalan Musul'un düşmesi ve ahalisinin katledilmesi Suriye'de endişe ve karışıklıkların başlamasına sebep olmuştu. Bölgede Moğol korkusu iyice yayılınca Baybars, Moğolların el koymaması için Musul-Haleb arasındaki ekinlerin yakılmasını emretti. Bu tedbirlere rağmen Dımaşk halkı Mısır'a göç etmeye başladı. Tam bu sırada Hülagu ile Alunordu hanı Berke arasındaki mücadelede Moğolların yenilmesi durumu biraz rahatlatu ${ }^{21}$. Bu durum Baybars ile Berke'yi Hülagu'ya karşı birbirine yaklaştırdı.

\section{Moğollar'a Karşı Memlûk-Altunordu İşbirliği}

Alunordu hüümdarı Berke Han, XIII. asrın ikinci yarısında Müslüman olmuş ve putperest Moğollar'a karşı Sultan Baybars ile ittifak yoluna gitmiştir. İzzeddin Keykavus da bu cepheye mensup olmak ve bu durumdan istifade etmek istiyordu. Bu durumun farkında olan Memlûk Sultanı Baybars 1263 'te Berke ve İzzeddin Keykavus'un elçilerini aynı zamanda kabul etti. Berke Han, Memlûk Sultanı'na Müslüman olduğunu bildirerek müttefik olmanın lüzumunu anlatıyordu. Kendisinin kuzeyden, Sultan Baybars'ın da Doğu Anadolu yönünden hareket etmesini bildirdi. Bu durum Baybars'ın da işine geliyordu.

Moğollara karşı Memlûk-Alunordu işbirliği Orta Doğu'da siyasi dengeyi değiştirmiştir. Bu arada Bizans imparatoru Mihael daha önce Baybars'ın elçilerini iyi karşılamış olmasına rağmen Hülagu'nun baskısıyla 1264'te İstanbul' dan geçen Memlûk elçilerini tutuklattı. Buna kızan Sultan Baybars, tebaasındaki Papaz ve Patrikleri çağırarak ahdinden dönenin durumunu sordu. Onlar da cezasının aforoz olduğunu söylediler. Sultan Baybars, İmparator

${ }^{21}$ Makrizi, Kitābu's-Sülūk li-Ma'rifet-i Düveli'l-Mülūk, C.1,K.2, s.433; İbn Haldun, Kitabu'İber ve Divanu'I-Mübteda ve'l-Haber, C.V, s.436; Baybars Tarihi (Çev. Şerafettin Yaltkaya7. İstanbul, 1941, s. XII-XIII; Şahabettin Tekindağ, Berkuk Devri, s.29; J.B.Globb, a.g.e., s.57-64; Şahabettin Tekindağ, "Memlûk Sultanlığı Tarihine Toplu Bakış" s.26; Kâzım Yaşar Kopraman, "Memlûkler", Doğuştan Günümüze Büyük İslam Tarihi, s.461-464; Steven Runciman, a.g.e., C. 3, s. 268. 
Mihael'e Fariseddin Akkuş ile birlikte bir Yunan filozofu, bir rahip ve bir papaz gönderip ona ağır bir şekilde hitap edince elçiler serbest bırakıldı.

Orta Doğu'da Memlûk ve Altunordu gibi iki büyük devlet İlhanlılara karşı siyasi ve dini sebeplerle olduğu kadar iktisadi ve kültürel çıkarlar bakımından da sıkı ilişki içindeydiler. Bu da İstanbul Boğazı yolunun kendilerine açık bulunmasını gerektiriyordu. Zira kuzeyin köle ve cariyeleri, kürkleri İslam dünyası için ne kadar lazım idiyse İslam dünyasının kumaşları ve çeşitli mamul malları da kuzey kavimleri için o kadar önemliydi. Yine İslam dünyası için Kıpçak çocukları askerlik için en mühim ihtiyacı teşkil ediyordu. Her türlü ticari maddeler gibi köleler de Kırım sahillerinden satın alınıp Sinop ve Samsun limanlarına çıkarılıyor, Anadolu'da Sivas'ta, Suriye'de Haleb'deki pazarlarda satılıyordu. El-Ömerî, kuzeyde Kıpçak, Rus ve Çerkeslerin birbirlerini esir edip Suğdak'ta Müslüman tüccarlara sattıklarını, kıtlık zamanlarında bizzat ailelerin çocuklarını tüccarlara verdiklerini yazar ${ }^{22}$. Kayseri-Suriye yolu üzerinde bulunan Yabanlu Pazarı her yıl milletler arası tüccarların toplandığı bir panayır yeri olup doğu-batı ve kuzey-güney malları burada mübadele olunurdu ki bunlar arasında Kıpçak ve Rum köle ve cariyeleri en mühim ticari emtiaydı. Memlûk Devleti ordusunun tamamına yakın bölümü Kıpçak kölelere dayanıyordu. Bu köleler arasında kumandan, vali, ilim ve kültür adamı da çokça yetişiyordu. Selçuklular zamanından beri Mısır ve Suriye'de kuvvetlenen Türk hakimiyeti Kıpçakların gelmesi ile o derece artu ki Arap kaynakları Memlûk Devleti'ne "Türk Devleti"23 ismini vermeye başladı$\operatorname{lar}^{24}$.

Moğollar Türkiye'yi tamamıyla tahakkümleri altına alınca düşman gördükleri Memlûk ve Altunordu devletlerinin münasebetlerini kesmek ve özellikle askeri kuvvetin kaynağı olan köle akınını önlemek için Anadolu yollarını kontrollerine almışlardı. Bu sebeple İstanbul yolu büyük bir önem kazanmıştır. Nitekim Bizans müellifi Pachymeres "Mısır Sultanı Kıpçaklardan bir köle iken sultan olmuştu. $\mathrm{O}$, tebaasının kendi milleti ile ticari münasebetlerini devam ettirmesini istiyordu. Kıpçakları satın alıp hudutların muhafazasına bırakıyordu. Fakat onları Karadeniz'den geçirmek zorluğu ile kaşılaşukları için bu denizin ağzını tutan imparatordan müsaade almışlar" der-

${ }^{22}$ El-Ömeri'den nakleden Osman Turan, Selçuklular Zamanında Türkiye, s.501.

${ }^{23}$ Buradaki "Türk" kelimesi burada etnik manada kullanılmamaktadır. Buradaki "Türk" kelimesi "Memlûk" demektir.

${ }^{24}$ Osman Turan, Selçuklular Zamanında Türkiye, s.501. 
ken hem bu durumu belirtmekte hem de Rum tarihlerine mahsus bir taassupla bu müsaadenin kuvvet karşısında vukubulduğunu açıkça ifadeden çekinmektedir. İlhanlı Hükümdarı Abaka da Baybars'a "Sen Sivas'ta satın alınmış bir kölesin. Dünya hükümdarlarına karşı nasıl muhalefet edebilirsin" diye ona hakaret ederek bu durumu gündeme getirmiştir ${ }^{25}$.

Bu köle ticareti Memlûkler için 14. asırda da önemini korumuştur. Nitekim bu asırda Orta Anadolu hükümdarı Kadı Burhaneddin, Mısır Sultanı Berkuk'un elçilerine "Bundan sonra Rum (Anadolu)'dan Suriye'ye Çerkes kölelerinin sevkine müsaade etmeyeceğim" dediği zaman bu söz ciddi bir endișe kaynağı olmuştu ${ }^{26}$.

İște bütün bu gelişmelerin de etkisiyle Altunordu Devleti'yle işbirliği yapan Baybars, Kerek Eyyûbi Emirliği'ni te'dib ettikten sonra, Humus Eyyûbi emirinin ölmesinden sonra Humus'u da Memlûk topraklarına kattı ve hemen ardından da tekrar Moğollarla mücadeleye döndü.

1265 yilında Moğolların Birecik'i muhasara etmesi üzerine Baybars, Haleb ve Hama'ya haber göndererek Birecik'e yardım göndermelerini istedi ve kendisi de hemen Kahire'den yola çıktı. Baybars'ın 15 gün sonra Gazze'ye ulaştığını öğrenen Moğollar kuşatmayı kaldırdılar. Muhasaranın kalktığını ögrenen Baybars emirleri Birecik kalesini onarmalarını ve Mısır ve Suriye'den savaş araçları getirerek kaleyi tahkim etmelerini istedi. Ayrıca 10 yıllık erzak depolamalarımı tavsiye edip Haçlılarla mücadeleye başladı. Zira Suriye sahillerinde müstahkem mevkilerde yaşayan Haçlılar her firsatta Müslümanlara saldırıp zarar verdiklerinden bu devletçikleri ortadan kaldırmak niyetinde olan Baybars, Filistin'deki Kayseriyye, Hayfa ve Arsuf kale ve şehirlerini hakimiyetine aldı. Ardından da Kahire'ye döndü ${ }^{27}$.

XIII. yüzyılın ikinci yarısında Anadolu'da Moğol baskısı gittikçe artmaya başladığından Anadolu'dan, Baybars'ın idaresinde bulunan topraklara, çok sayıda Türkmen iltica etmeye başladı. Memlûk müverrihi İbn Şeddad, Bay-

${ }^{25}$ Makrizi, Kitābu's-Sülūk li-Ma'rifet-i Düveli'l-Mülûk, C.1, K.2, s.474-475; Esterabadi, Bezm u Rezm, (Çev. Mürsel Öztürk), Ankara, 1990, s.342; Osman Turan, Selçuklular Zamanında Türkiye, İstanbul, 1991, s.4398-502.

${ }^{26}$ Osman Turan, Selçuklular Zamanunda Türkiye, s.501-502.

${ }^{27}$ Makrizi, Kitābu's-Sülūk li-Ma'rifet-i Düveli'l-Mülûk, C.1, K.2, s.495; İbn Haldun, Kitabu'lIber ve Divanu'l-Mübteda ve'l-Haber, C.V, S.426 VD.; Baybars Tarihi, s. 17-18; Kâzım Yașar Kopraman, "Memlûkler", Doğuştan Günümüze Büyük Islam Tarihi, s.458-459; Bertold Spuler, a.g.e., s.83-89; Faruk Sümer "Anadolu'da Moğollar", s.237-238. 
bars zamanında 40 bin çadır Türkmen'in Suriye'ye geldiğini bildirmekte$\operatorname{dir}^{28}$.

Baybars zamanında Moğol istilasından kaçarak Suriye'ye gelen Türkmenler, Gazze'den Antakya ve Sis'e kadar olan bölgede yurt tutmuşlardı. Gerçekten de Suriye'de Memlûkler devrinde olduğu kadar hiçbir devirde bu kadar çok Türkmen toplanmamışur. Bu Türkmenlerin büyük çoğunluğu yaz gelince Maraş, Uzunyayla ve Sivas taraflarına geliyorlardi ${ }^{29}$.

1269 yllı Şubat'inda Baybars'ı yine ordusunun başında Suriye'de görüyoruz. Dımaşk'a geldiği zaman İlhanlı Hükümdarı Abaka'nın elçilerini kabul etti. Abaka tekrar Baybars'a bir köle olduğunu ve bir hükümdarla uğraşamayacağını anlatıyordu. Buna aldırmayan Baybars, Abbasi topraklarını kurtarıncaya kadar savaşacağını söyledi ${ }^{30}$.

$\mathrm{Bu}$ arada barıştan ümidini kesen Abaka, Suriye sahillerindeki Haçlılarla yeni anlaşmalar yaparak komutanlarını İslam topraklarına gönderdi. Ardından da Haleb civarındaki Sacur'a saldırdı. Bunu haber alan Baybars hemen Alaaddin Bundukdar komutasındaki bir orduyu Suriye'ye gönderdi. Ekim 1269 'da kendisi de Suriye'ye gitti. Dımaşk'a gelince Moğollar'ın çekildiğini öğrendi ve Mısır'a döndü.

1271 yılında Haleb ve civarına bir başka Moğol saldırısı daha oldu. Abaka sık sık elçiler göndermekle beraber Suriye ve civarına saldırıları da tekrarlıyor, Memlûk kuvvetleri gelince de geri çekiliyordu.

Memlûk-Moğol mücadelesi 1277 yılında yeniden başladı. Bu tarihte Türkiye Selçuklu tahtında 17 yaşındaki III. Gıyaseddin Keyhüsrev vardı. Devletin gerçek idarecisi Muineddin Süleyman Pervâne idi. Devletin her kadrosunu hemşehrileri İranlılarla dolduran Pervâne, sırunı Moğollar'a dayadığından onları para ile tatmin etmek için elinden geleni yapıyordu. Buna

${ }^{28}$ Baybars Tarihi, s.155, 171; Faruk Sümer, Oğuzlar (Türkmenler), Ankara, 1972, s.159.

29 Makrizi, Kitab-1 Sülûk li Ma'rifet-i Düveli'l Mülûk, C.1, K.2, s.457-462; Faruk Sümer Oğuzlar, İstanbul, 1992, s.70; Ali Aktan "Mısır'da Abbasi Halifeleri" Belleten, C.55, S.214, s.613648.

${ }^{30}$ Baybars kendisine iltica eden bir Abbasi emirini Mısır'da kabul edip "El-Mustansır" lakabıyla hilafet makamına oturtmuştur. Halife de buna karşılık ona, Mısır ve Suriye'nin yanı sıra fethedeceği yerlerin de sultanı unvanın vermiştir. Bak. Makrizi, Kitab-ı Sülûk li Ma'rifet-i Düveli'l Mülûk, C.1, K.2, s.457-462; İbn Haldun, Kitabu'l-Aİber ve divanu'l-Mübteda ve'l-Haber, C.V, s.426 vd.; J.B. Globb, a.g.e., s.68-103; Ali Aktan, "Mısır'da Abbasi Halifeleri", Belleten, C.55, S.214. 
rağmen Moğollar'ın, devlet işlerine müdahalesini önleyemiyordu. Moğollar'in sonu gelmeyen maddi istekleri Pervâne'yi bunalunca bu duruma bir son vermek için Sultan Baybars ile haberleşmeye başladı.

Baybars ile Pervâne arasında yapılan anlaşmaya göre Baybars, Türkiye Selçuklu Devleti'ni Moğol tahakkümünden kurtaracak, buna karşılık kendisine her yll vergi verilecekti. Bu sırada Moğol Hükümdarı Abaka ise Celayirlilerden Toku'yu Anadolu'daki Moğol kuvvetlerinin başına tayin etti ve Pervâne'ye de Toku'dan izinsiz hareket etmemesini söyledi ${ }^{31}$.

İbn Şeddâd'a göre Muineddin Süleyman Pervâne'nin teklifiyle Kahire'den ayrılan Baybars, Kilikya üzerine yürüdü. Dımaşk'a gelmeden önce Birecik'te tahkimat yapturarak Ayas, Messisa ve Adana'yı zaptetti. Daha Dımaşk'ta iken 30 bin kişilik Moğol-Selçuklu ortak ordusunun Birecik'e saldırdığını duyunca hemen harekete geçti ancak muhasaranın kaldırıldığını ögrenince geri döndü.

Baybars bu tarihten sonra Anadolu'ya girmeye karar verdi. Moğol baskısından kaçıp Suriye'ye iltica eden bazı Selçuklu emirleri de onu bir Anadolu seferine teşvik ediyorlardı. 1277'de yola çıkan Baybars, önce Dımaşk'a oradan da Haleb'e geldi. Haleb'den Anadolu içlerine doğru hareket eden Baybars aynı yıl Elbistan civarında Moğol kuvvetleriyle karşılaştu.

Baybars bu hareket sırasında Pervâne'nin kendisine katılmasını bekliyordu. Ancak Pervâne ortada yoktu. Gürcülerle desteklenen Moğol kuvvetleri ile Baybars'ın ordusu Elbistan'ın Hunu Köyü yakınında karşılaştu ve çetin bir savaştan sonra Moğol kuvvetleri yenildi. Savaş sonuna kadar ortadan görünmeyen Pervâne, Moğol yenilgisini haber alınca hemen Kayseri civarına gelip oradan Tokat'a geçti ${ }^{32}$.

Baybars zaferden sonra Kayseri'ye geldi ve halk tarafindan sevinçle karşılandı. Burada adına para basturıp hutbe okutan Baybars, burada bir durum değerlendirmesi yapıp Pervâne'nin oynadığı oyunu fark etti. Bu sırada Elbistan bozgunundan sorumlu tutulan Pervâne, Abaka tarafından Aladağ'da öldürülmüştü.

${ }^{31}$ Muineddin Süleyman Pervâne hakkında geniş bilgi için bkz. Baybars Tarihi, s.84-92; Nejat Kaymaz, Muineddin Süleyman Pervâne, Ankara, 1970; Faruk Sümer "Anadolu'da Moğollar", s.15-69.

${ }^{32}$ Makrizi, Kitab-1 Sülûk li Ma'rifet-i Düveli'1 Mülûk, C.1, K.2, s.495; Baybars Tarihi, s.17-18; Osman Turan, Selçuklular Zamanında Türkiye, s.526-527; Faruk Sümer, Yabanlu Pazarı, s.56-57. 
Baybars'in Anadolu'dan ayrılmasından sonra Abaka, Anadolu'ya geldi. Savaş alanında gördüğü Moğol cesetlerinin kendisine verdiği hınçla kendisine itaat etmeyen Türkmenleri büyük bir katliama tabi tuttu. Memlûk müverrihleri Abaka'nın 200 bin kişiyi bu sırada katlettiğini kaydederler ${ }^{33}$.

Baybars'ın 1277 Anadolu seferiyle, Anadolu'nun güney kısımlarına sahip olarak Suriye'nin güvenliğini sağlamak istediği anlaşılmaktadır. Kayseri'de adına para kestirip hutbe okutması bunun önemli bir işaretidir. Ayrıca o her firsatta Suriye'ye saldıran ve üzerine Memlûk ordusu gelince çekilen Moğol ordusuna kati bir darbe vurup Suriye'yi Moğol saldırısından emin kılmak ve Haçlı ve Ermenileri Moğol desteğinden mahrum bırakarak onlarla rahatça uğraşmak istiyordu.

\section{Kalavun ve Moğollar}

Baybars zamanında yoğun bir şekilde devam eden Memlûk-Moğol mücadelesi Kalavun $^{34}$ devrinde yeniden başladı.

Kalavun'un ilk yıllarında Moğollar, Memlûkler'in kendi aralarında düştükleri ihtilaftan ve Şemseddin Sungur'un yardım talebinde bulunmasından yararlanmak düşüncesiyle Suriye'ye girdiler. Esasen bu tahrikler Ayn-1 Câlût ve Elbistan mağlubiyetlerini bir türlü unutmayan İlhanlı hükümdarı için birer bahane idi. Haleb, Ayntab, Bagras ve Derbesak's istila ederek yağma ve talanda bulundular. Halkın çoğu kaçarak Mısır sınırına dayandı. Ancak Moğollar, Sungur'un kendileriyle ortak hareket etmekten vazgeçmesi üzerine istila ettikleri yerlerde fazla kalmayarak aldıkları ganimetlerle kendi ülkelerine geri döndüler. Fakat bir yll sonra tekrar Suriye'de göründüler. Abaka Han Rahbe kalesine indi. Kardeşi Mengütemür ise içinde bir miktar Ermeni, Gürcü ve Frenklerin de bulunduğu ordusunun başında Hama'ya kadar ilerledi. Humus yakınlarında Memlûk ordusuyla karşılaşan Mengütemur büyük bir yenilgiye uğradı. Rahbe'deki Abaka Han, kardeşi dahil Memlûkler'in elinden canlarım kurtarabilenlerin kendisine iltihak etmesinden sonra Bağ-

${ }^{33}$ Baybars Tarihi, s.84-92; Osman Turan, Selçuklular Zamanında Türkiye, s.526-526; Faruk Sümer, Yabanlu Pazarı, s.60-62; Nejat Kaymaz, a.g.e., s.139-179; Sahabettin Tekindağ, "Memlûk Sultanlığı Tarihine Toplu Bakış", s.26; Faruk Sümer Oğuzlar, s.134-135; J.B.Globb, a.g.e., s.68103; Bertold ZSpuler, a.g.e., s.88.

${ }^{34}$ Kalavun devri hakkında geniş bilgi için bkz. el-Makrizi, Kitābu's-Sülūk li-Ma'rifet-i Düveli'l-Mülûk, C.1, K.3, s.681 vd.; Ali Aktan "Bahri Memlûklerdan Kalavun ve Hanedanı" Belleten, C.59, S.226, s.608-618. 
dad'a gitti. Muzaffer olarak Kahire'ye dönen Kalavun ise burada muhteşem bir törenle karşılland ${ }^{35}$.

Abaka'nın ölümünden sonra İlhanlı tahtuna, İslam dinine girerek Ahmed adına almış olan Teküdar, Bağdad fukahasına ve Sultan Kalavun'a mektup yazarak kendisinin Müslüman olduğunu ve İslam'a hizmet etmek istediğini samimi bir şekilde ifade etti. Kalavun ise cevabında onu tebrik ediyor ve iki devlet arasındaki düşmanlığın zamanla yok olacağını bildiriyordu. Gerçekten söz konusu düşmanlık yatışmaya başlamıştı. Ne var ki Moğollar, Teküdar'ın Müslüman olmasını ve kendilerini İslam'a sokmak istemesini hoş karşılamıyorlardı. Bu yüzden Moğol erkanı Teküdar'ı hal ve katlederek yerine yeğeni putperest Argun'u geçirdiler. Argun ilhanlı adliye ve maliye teşkilatında yer edinmiş olan Müslümanları görevinden uzaklaştırmakla işe başladı. Tabii bu durum İlhanlı-Memlûk münasebetlerinin tekrar bozulmasinda etkili oldu ${ }^{36}$.

\section{Nâsıreddin Muhammed ve Moğollar}

Nâsıreddin Muhammed devrinde de Moğollar'ın Memlûklere karşı geleneksel düşmanlık politikası devam ediyordu. Moğol hükümdarı Gazan Han, ülkesine sığınan Memlûk emirlerinin de teşvikiyle Suriye üzerine sefere hazırlanmaya başladı. Ancak Bağdad'a geldiği sırada Anadolu umumi valisi Sülemiş'in, Cengiz'in daha yakın akrabası olduğu iddiasıyla, İlhanlı tahtımı ele geçirme hareketi ile karşılaşt. Bu hareketi haber alır almaz Suriye seferinden vazgeçti. Gazan Han'ın üzerine gelmesi ile onun karşısında duramayan Sülemiş Memlûklere sığınmak zorunda kaldı. Sülemiş'in, ailesini getirmek amacıyla emrine verilen Memlûk askerleriyle Mardin'i yağmalaması Gazan Han'ın yeni bir Suriye seferi için bahane oldu. Gazan Han'ın sefer hazırlıklarını haber alan Nâsıreddin Muhammed ordusunu hazırlayarak Dımaşk'a doğru harekete geçti. 1299 yılı sonlarında Gazze'ye, oradan da Dımaşk'a ulaşuğında Gazan Han'ın Fırat'ı geçtiği haberini aldı. Hemen onu karşılamak üzere harekete geçerek Hama ile Humus arasındaki Haznedar vadi-

${ }^{35}$ Osman Turan, Selçuklular Zamanında Türkiye, s.574-575; Bertold Spuler, a.g.e., s.83-88; Steven Steven Runciman, a.g.e., C.3, s.329-330; Abdulkadir Yuvalı, Ilhanlılar Tarihi, s.44; Franz Taeschner "1453 Yilına Kadar Osmanlı Türkleri" (Çev. Necmi Û̉lker) Ege Üniversitesi Tarih Incelemeleri Dergisi, S.IV, s.283-309; Ali Aktan "Bahri Memlûklerdan Kalavun ve Hanedanı" s.612-613.

${ }^{36}$ Steven Steven Runciman, a.g.e., C.3, s.329-330; Abdulkadir Yuval, Ilhanllar Tarihi, s.44; Ali Aktan "Bahri Hanedanı" s.612-613. 
sinde onunla karşılaştu. Yapılan savaşta Nâsıreddin Muhammed yenildi ve Humus, Moğolların eline geçti. Ancak Gazan Han, Humus'u almakla yetinmeyerek Dımaşk üzerine yürüdü. Moğolların gelişini haber alan şehir halkı şehri hemen boşalttı. Gazan Han, İbn Teymiye ve Bedreddin Cemaa'nın ricasıyla halka aman verdi ve Moğol kumandanı Emir Kıpçak şehre girdi. Ne var ki kale kumandanı Arcavaş'ın teslim olmaması yörede bir çok katliam ve yağmaya sebep oldu.

Bu sırada İlhanlıların doğudan gelen ırkdaşlarının tehlikesi altında olması sebebiyle Gazan Han, Mısır'a sonbaharda yeniden geleceği tehdidini savurarak Suriye'den ayrıldı. Onun ayrılmasından sonra, daha önce Moğollara yenilmiş olan Nâsıreddin Muhammed, gerekli hazırlıkları yaptıktan sonra Suriye'ye hareket etti. Suriye'de bulunan Moğol kumandanı Kıpçak'a haber göndererek kendisine tabi olmaya çağırdı. Bu teklifi olumlu karşılayan Kıpçak, Memlûk tabiiyetine girmiş ve böylece 100 gün sonra Dımaşk'ta hutbe yeniden Memlûkler adına okunmuştur. Dımaşk'ın ilhakını Haleb'in alınması takip etti. Ancak bütün bu olanların üzerinden 5 ay geçmeden Moğollar yeniden Suriye üzerine sefere çıktı. Bu durum tekrar bölge halkının yerlerini bırakarak kaçmasına sebep oldu. Ancak İbn Teymiye'nin teklifi ile Dımaşk'tan çıkışların izne bağlanması ve Nâsıreddin Muhammed'in ordusunun başında Suriye'ye gelmesi göçü az da olsa önledi ${ }^{37}$.

Sultan Nâsıreddin Muhammed Gazze'ye geldiğinde Gazan Han'ın Antakya civarında olduğunu öğrendi. Fakat içinde bulunduğu durum bir savaşa girmeye müsait değildi. Bu sebeple Mısır'a geri döndü. Onun dönüşünü haber alan halk tekrar göç etmeye başladı. Bu durum karşısında paniğe kapılan Ibn Teymiye, Sultan'a haber göndererek Suriye'ye yardıma gelmezse Dımaşk' a başka sultan seçeceklerini bildirdi. Öte yandan iklim şartlan Haleb, Kurun, Hama, Şeyzer ve Maarra'yı işgal eden Gazan Han'ı çok zor durumda bıraktığı için kendisi için alınması kolay olan Dımaşk üzerine hareketten vazgeçerek geri döndü. Bu durum bölge halkını oldukça sevindirmiştir.

Gazan Han, Suriye'den dönerken sulh teklifinde bulunmuştu. Ancak bu Memlûk sultanı tarafından reddedilmişti. Zira bu teklifi zaman kazanıp toparlanabilmek için yapmışu. Nitekim onun 1 yl sonra 3 . kez Suriye seferi hazırlıklarına başlaması da bunun en güzel işaretidir.

${ }^{37}$ Makrizi, Kitābu's-Sülūk li-Ma'rifet-i Düveli'l-Mülûk, C.1, K.3, s.683; Bertold Spuler, a.g.e., s.109-118. 
1303 yılında Memlûk donanması Akdeniz'deki Arvad Adası'na hücum edip sahiller için tehlikeli bir güç olan Templierlerin elinden burayı almakla uğraşırken bu yılın Receb ayında Moğolların Suriye'ye saldıracakları haberi geldi. Bu yıl içinde iki kuvvet arasında Tedmür civarında cereyan eden savaş Memlûk zaferi ile neticelendi. Bunun intikamını alma hırsı içine giren Moğollar, Ermeni ve Gürcülerin de katulımıla oluşan 100 bin kişilik bir ordu ile Humus ve Baalbek üzerine yürüdü. Moğol ordusu geçtiği yerleri yakıp yıkt. Memlûk ordusu derhal Moğollar üzerine hareket etti. İki ordu Mercu's-Suffer'de tekrar karşılaşt ve Moğollar bir kez daha yenildi. Zaferden sonra D1maşk'a uğraşan Sultan, Mısır'a döndü.

Gazan Han'ın ölümünden sonra yerine geçen Olcaytu, Memlûk-Altınorda ittifakını önlemek amacıyla barış yapmak istiyordu. Ancak Altınordu Hanı'nın Şiiliği kabul etmesi, Memlûk-Altınordu ilişkilerinin kendiliğinden bozulmasına sebep oldu. Bunun neticesi olarak Papa, İngiltere ve Fransa'yı Mısır ve Suriye üzerine sefere teşvik etmeye başladıysa da bu ülkelerdeki iç karışıklıklar ve Orta Doğu'daki Haçlı emirliklerinin büyük oranda ortadan kaldırılmış olması böyle bir harekete girmelerini engellemiştii ${ }^{38}$.

Nâsıreddin Muhammed üçüncü kez Memlûk tahuna geçtiğinde Memlûk ülkesindeki Moğol tehdidi tekrar başlamışt. Zira Nâsıreddin Muhammed üçüncü kez başa geçtikten hemen sonra Suriye'deki emirlerden bazılarının yerlerini değiştirmiş, bazılarını da tutuklatmıştı. Bu durum diğer emirleri de tedirgin etmeye başlamışt. Nitekim Dımaşk naipliğinden Haleb naipliğine atanan Karasungur, tevkif edileceği endişesiyle İlhanlılara iltica etmek istiyordu. Arkadaşları ile Fırat'ı geçip Mardin'e gitti. Şehir valisi tarafindan çok iyi karşılanan Karasungur, Olcaytu'nun huzuruna giderek onu Suriye üzerine sefer yapmaya teşvik etmeye başladı. Olcaytu da bu teşvik ve tahriklerin de tesiriyle Suriye'ye yürüdü. Durumu öğrenen Nâsıreddin Muhammed askeri hazırlıklarını tamamlayarak 1313 ylında Kahire'den hareket etti ise de yolda daha önce Rahbe şehrini muhasara eden Olcaytu'nun geri döndüğünü öğrenince buradan hacca gitti ${ }^{39}$.

Buraya kadar verilen bilgilerden de anlaşılabileceği gibi Memlûk Devleti kuruluşundan itibaren Suriye üzerine düzenlenen Moğol saldırılarıyla uğ-

${ }^{38}$ Makrizi, Kitābu'šSülūk li-Ma'rifet-i Düveli'1-Mülûk, C.1, K.3, s.691; İbn Haldun, Kitabu'tİber ve Divanu'1-Mübteda ve'1-Haber C.V. s.473; Bertold Spuler, a.g.e., s.109-118.

${ }^{39}$ Makrizí, Kitābu's-Sülūk li-Ma'rifet-i Düveli'l-Mülûk, C.1,K.3, s.699; İbn Haldun, Kitabu'lİber ve Divânu'l-Mübteda ve'l-Haber C.V, s.473; Bertold Spuler, a.g.e., s.132-143. 
raşmak zorunda kalmışur. Belki de Suriye'den sonra Mısır'a yürüyüp bütün İslam dünyasına zarar verebilecek olan Moğollar Suriye'de Memlûklerce durdurulmuşlardır. Moğolların Memlûklerce mağlup edilmesi onların yenilemeyeceği fikrini de yıkmıştur.

Moğolların, Suriye üzerine olan seferlerinin bölge üzerinde ekonomik, sosyal ve siyasi neticeleri olmuştur.

Moğolların Suriye'de ele geçirdikleri yerleri yakıp yıkmaları bölge ekonomisine darbe vurmuştur. Halk, Moğollar'ın faydalanmasını engellemek amacıyla ekinleri bizzat kendi elleriyle yakmıştur. Bölgede güvenliğin kaybolmasının tabii bir neticesi olarak ticaret yollarının güvenliği de kaybolmuş, ticaret durmuştur. Buna Moğollar'a karşı hazırlanan orduların maddi ihtiyaçlarını karşılama zarureti de eklenince büyük bir ekonomik gerileme söz konusu olmuştur.

Moğolların bölgedeki yağma ve katliamlarının halk üzerinde doğurduğu korku ve panik havası, binlerce insanın bölgeden ayrılarak Anadolu, Mısır ve diğer civar bölgelere göç etmesine sebep olmuştur. Bu nüfus hareketliliği bazı bölgelerin boşalması neticesini doğururken, bazı bölgelerde de aşırı nüfus artışına sebep olmuştur.

Moğolların Suriye üzerine saldırılarının siyasi neticelerine gelince:

Bilindiği üzere Haçlı Seferleri sırasında başta Kudüs ve Suriye'nin sahil şehirlerinde çeşitli Haçlı kontluklanı kurulmuştu. Memlûkler'in temel politikalarından birisi de bölgeyi Haçlılar'dan temizlemekti. Her ne kadar Haçlılar, Ayn-ı Câlût Savaşı sırasında tarafsız kalarak Memlûk ordularının topraklarından geçmesine izin vermişlerse de, bölgenin Haçlılar'dan temizlenmesi yaklaşık yarım asır gecikmiştir. Baybars ve halefleri Suriye'yi Haçlılar'dan temizlemek için uzun süre mücadele etmiştir. Zira Haçlılar, Memlûk Devleti ile iyi geçinmeye çalışmalarına rağmen, icra ettikleri casusluk faaliyetleri ile her zaman bir iç tehdit unsuru olmaya devam ediyorlardı. 
